\title{
Mathematical Relationship for Influencing Amount of Water and Plant Distance on Bottle Gourd Plant Production
}

\author{
Rewaa. S .El shatoury ${ }^{1}$ and A.K.Mahmoud ${ }^{2}$ \\ ${ }^{1}$ Department of Horticulture-Faculty of Agricultural-Suez Canal University, Ismalia, EGYPT \\ ${ }^{2}$ Physical and soil chemistry department-Desert Research Center (DRC), Cairo, EGYPT
}

\begin{abstract}
The field experiment was conducted to assess the influence of different amounts of water and different plant distances on (Lagenaria siceraria) Bottle Gourd's production. The experiment was laid out on spilt plot design with amounts of water as a main plot factor comprise three treatments (T1, T2 and T3) with average (16,32 and $64 \mathrm{~m}^{3} / \mathrm{fed} /$ day) respectively; and plant distance as sub-blot factor comprise two treatments (d1 and $d 2)$ with $(0.75$ and $0.5 \mathrm{~m})$ respectively. The results revealed that amounts of water and plant distance have a significant interaction effect on yield production. Likewise, a significant interaction was observed on No. of fruits $(P=0.05)$. However, $d 2$ has obtained a significant impact on yield production comparing with d1. Nevertheless, high water use efficiency was recorded with low amount of water (T1) which was $2.7 \mathrm{~kg} / \mathrm{m}^{3}$ with both different plant distances.
\end{abstract}

Key words: Bottle Gourd, water amount, plant distance and water use efficiency.

\section{Introduction}

Numerous of countries have suffering from water scarcity and impairment management for water resources, thus; they focusing to deal with this problematic by more rationalized and efficient manner than ever before. Therefore, two issues that need attention are a) finding means of lowering the current level of water demand by some efficient water use techniques, and b) promote economic return to the farmers to enhance economic incentives. These can be obtained through high crop production and increasing the water productivity using new irrigation approach.

Localized irrigation system specially (drip irrigation technique) has considered the vital approach for manipulating crop growing and to increase yield and improve production. In addition, this method is widely used because it allows efficient management of both water and fertilizer (Rajurkar et al., 2012). Dry season vegetables production such as bottle gourd and okra through cost-effective techniques of irrigation and fertilization seems promising. But decreased water availability during this season has been identified as a constraint on vegetable production ( Yih-Chi Tan, et al 2009 ). Likewise, the role of irrigation at proper level and stages of plant growth has great significance in improving the yield (Singh et al., 1990).

The most useful measure of performance of an irrigation system, in terms of its effect on crop yield, is the water use efficiency (WUE) (Alghariani, 2002) which evaluates the proportion of the applied water beneficially used by the crops, WUE often defined by the ratio between the crop biomass or grain production and amount of water consumed by the crop, including rainfall, or the irrigation water applied, or the crop transpiration (zhang and oweis,1999). sometimes the term of WUE is used as synonymous of application efficiency ( $\mathrm{AE}, \%$ ) or irrigation efficiency. Likely, the term WUE should be used as an indicator of the plants performance ( Luis,S.Pereiar. et al 2002).

The growth of the vegetable market even during the dry season and the improved nutritional awareness of people, have attracted farmers to bring greater areas under vegetable farming in summer and spring seasons in the foot-hill and plain areas of Nepal. However, dry weather during this season creates a condition of water scarcity for many crops requiring frequent irrigation. Several studies reported mulch to conserve soil moisture and improve crop yield (Singh et al., 1976).

Bottle gourd fruits are generally grown as a vegetable in Africa and Asia. Immature fruits are consumed by boiling, frying, or stuffing like the fruit of Cucurbita pepo. Shoots, tendrils, and leaves are also cooked, and the seeds are used for oil extraction or for cooking. The tendrils and young leaves are also utilized for some medicinal purposes (Tindall 1983). Moreover; Bottle gourd has also been used routinely as a source of rootstock for watermelon and other cucurbit crops in some countries to reduce the incidence of soil-borne diseases and to develop the vigor of the root system of the crop under conditions of low temperature (Lee and Oda 2003).

A model is a schematic representation of the conception of a system or an act of mimicry or a set of equations, which represents the behavior of a system. Also, a model is "A representation of an object, system or idea in some form other than that of the entity itself". Its purpose is usually to aid in explaining, understanding or improving performance of a system. A model is, by definition "A simplified version of a part of reality, not a 
one to one copy". This simplification makes models useful because it offers a comprehensive description of a problem situation. However, the simplification is, at the same time, the greatest drawback of the process. It is a difficult task to produce a comprehensible, operational representation of a part of reality, which grasps the essential elements and mechanisms of that real world system and even more demanding, when the complex systems encountered in environmental management (Murthy, 2002). There are a many types of modes; for instance Statistical models: These models express the relationship between yield or yield components and weather parameters. In these models relationships are measured in a system using statistical techniques as Step down regressions, correlation, etc.

The aim of this paper is to study the influence of different both (plant distance and water quantities) on yield production, plant parameters and finally a good water use in addition create a simple mathematic relation between yield and factor of experiments.

\section{Experimental location}

\section{Materials and Methods}

The experimental was carried out at farm faculty of agricultural - Suez Canal university Ismailia governorate The study site, established in late May of (2013-2014), (30 37' 10.91"N - 32 $\left.12^{\circ} 1.33^{\prime \prime} \mathrm{E}\right)$.

The site of experiment falls into an arid area with a Mediterranean climate. The site is about $30 \mathrm{~m}$ above sea level with an annual rainfall of $29 \mathrm{~mm} /$ year, temperatures of $21.6{ }^{\circ} \mathrm{C}$, relative humidity of $53.9 \%$, and wind speed of $2.5 \mathrm{~m} / \mathrm{s}$. The total annual evapotranspiration (ETo) is $1821 \mathrm{~mm} /$ year (table [1]).

Table 1: Climatic characteristics at Ismailia governorate.

\begin{tabular}{ccccccccc}
\hline \multirow{2}{*}{ Month } & Prc. & Wet days & $\begin{array}{c}\text { Tem. } \\
\mathbf{m a x}\end{array}$ & $\begin{array}{c}\text { Tem } \\
\mathbf{m i n} .\end{array}$ & Hum. & $\begin{array}{c}\text { Sun } \\
\text { shine }\end{array}$ & $\begin{array}{l}\text { Wind } \\
(\mathbf{2 m})\end{array}$ & ETo \\
\cline { 2 - 9 } & $\mathbf{m m} / \mathbf{m}$ & & ${ }^{\circ} \mathbf{C}$ & ${ }^{\circ} \mathbf{C}$ & $\mathbf{\%}$ & $\mathbf{\%}$ & $\mathbf{m} / \mathbf{s}$ & $\mathbf{m m} / \mathbf{d}$ \\
\hline Jan & 5 & 4.5 & 13.7 & 19.1 & 58.9 & 68.1 & 2.2 & 2.4 \\
\hline Feb & 5 & 3.5 & 14.9 & 20.7 & 56.1 & 70.1 & 2.6 & 3.2 \\
\hline Mar & 5 & 2.5 & 23 & 11 & 52.1 & 71.7 & 2.8 & 4.2 \\
\hline Apr & 2 & 1.1 & 28.1 & 14.6 & 46 & 74.1 & 2.8 & 5.7 \\
\hline may & 2 & 0.6 & 31.5 & 17 & 45.1 & 78.8 & 2.8 & 6.8 \\
\hline Jun & 0 & 0 & 34.4 & 20.1 & 48.4 & 87.3 & 2.8 & 7.5 \\
\hline Jul & 0 & 0 & 35.2 & 21.8 & 51.9 & 85.3 & 2.5 & 7.3 \\
\hline Aug & 0 & 0 & 34.9 & 22 & 54.6 & 86.5 & 2.4 & 6.8 \\
\hline Sep & 0 & 0 & 32.8 & 20.4 & 56.4 & 81.9 & 2.4 & 5.7 \\
\hline Oct & 1 & 1 & 29.7 & 17.5 & 57.2 & 82.9 & 2.4 & 4.6 \\
\hline Nov & 5 & 2 & 25.1 & 13.5 & 59.5 & 76.7 & 2 & 3.1 \\
\hline Dec & 4 & 3.4 & 20.6 & 9.7 & 61 & 65.5 & 2 & 2.3 \\
\hline
\end{tabular}

$($ Prc. $=$ Precipitation; Wet days $=$ Number of days per month with $>0.1 \mathrm{~mm}$ of precipitation; $T$ mp. $\min / \mathrm{max}=$ minimum/maximum temperature; hum. = relative humidity; Sun shine = Sun shine as percentage of day length; $\operatorname{Wind}(2 \mathrm{~m})=$ wind speed at $2 \mathrm{~m} ;$ ETo $=$ Reference evapotranspiration)

Analyses of soil and some physical and chemical characteristics were carried out according to Martin, (1993). These analyses are presented in tables [(2)and (3)]. The soil of the experimental site is sandy texture, none saline, and none calcareous. Silt and clay content are quite low there for both field capacity and available water are very low $(5.6 \%$ and $4.5 \%)$.

Table 2. Some chemical characteristic for the experimental site.

\begin{tabular}{|c|c|c|c|c|c|c|c|c|c|c|}
\hline \multirow{2}{*}{$\begin{array}{l}\text { Depth } \\
(\mathrm{cm})\end{array}$} & \multirow{2}{*}{$\mathrm{PH}$} & \multirow{2}{*}{$\begin{array}{c}\mathrm{Ec} \\
\mathrm{dS} / \mathrm{m}\end{array}$} & \multicolumn{4}{|c|}{ Soluble cations meq/l } & \multicolumn{4}{|c|}{ soluble anions meq/l } \\
\hline & & & $\mathrm{Ca}^{2+}$ & $\mathrm{Mg}^{2+}$ & $\mathrm{Na}^{+}$ & $\mathrm{K}^{+}$ & $\mathrm{CO}_{3}{ }^{2-}$ & $\mathrm{HCO}_{3}^{-}$ & $\mathrm{Cl}^{-}$ & $\mathrm{SO}_{4}{ }^{2-}$ \\
\hline $0-20$ & 5.63 & 0.21 & 1.1 & 0.15 & 0.67 & 0.18 & 0 & 0.6 & 0.61 & 0.89 \\
\hline $20-40$ & 5.76 & 0.1808 & 1.03 & 0.114 & 0.46 & 0.195 & 0 & 0.533 & 0.352 & 0.913 \\
\hline
\end{tabular}

Table 3. Particle size distribution for the experimental site.

\begin{tabular}{cccccc}
\hline \multirow{2}{*}{ Depth, cm } & \multicolumn{3}{c}{ Particle size distribution \% $(\mathrm{mm})$} & \multirow{2}{*}{$\begin{array}{c}\text { Textural } \\
\text { class }\end{array}$} \\
\cline { 2 - 5 } $0-20$ & C.Sand & F.Sand & Silt & Clay & S* \\
$20-40$ & 8.21 & 87.24 & 2.4 & 2.15 & $\mathrm{~S}^{*}$ \\
\hline $\mathrm{S}^{*}=$ sand & 10.61 & 85.12 & 3.1 & 1.17 & $\mathrm{~S}^{*}$ \\
\hline
\end{tabular}

\section{Irrigation system and cultivation.}


Used a trickle irrigation system [trickle (using GR $4 L / 50 \mathrm{~cm} / \mathrm{h}-1.2 \mathrm{bar}$ ). three amounts of water (T1, T2 and T3) with average $(16,32$ and $64 \mathrm{~m} 3 / \mathrm{fed} / \mathrm{day})$ respectively as a main plot factor. Moreover; plant distance as sub-blot factor comprises two treatments $(\mathrm{d} 1$ and $\mathrm{d} 2)$ with $(0.50$ and $0.75 \mathrm{~m})$ respectively. Likewise; the experiment applied for two seasons 2013 and 2014.

Water samples were analyzed by standard analytical methods for $\mathrm{pH}$, electrical conductivity and ion composition (APHA 1992). Average values of the analyzed parameters in irrigation water are given in [table (4)]

Table 4. Some chemical characteristic for the different irrigation water type.

\begin{tabular}{|c|c|c|c|c|c|c|c|c|c|c|}
\hline \multirow{2}{*}{$\mathrm{Ph}$} & \multirow{2}{*}{$\begin{array}{c}\text { EC } \\
(\mathrm{dS} / \mathrm{m})\end{array}$} & \multicolumn{4}{|c|}{ Soluble Cations (meq/L) } & \multicolumn{4}{|c|}{ Soluble Anions(meq/L) } & \multirow{2}{*}{ SAR } \\
\hline & & $\mathrm{Ca}^{++}$ & $\mathrm{Mg}^{++}$ & $\mathrm{Na}^{+}$ & $\mathrm{K}^{+}$ & $\mathrm{CO}_{3}^{-2}$ & $\mathrm{HCO}^{-3}$ & $\mathrm{CL}^{-1}$ & $\mathrm{SO}_{4}^{-2}$ & \\
\hline 7.34 & 1.18 & 2.8 & 0.6 & 8.2 & 0.2 & 0 & 2.92 & 6.83 & 2.05 & 6.36 \\
\hline
\end{tabular}

\section{Measurements and calculations}

Irrigation water use efficiency using the Bos, M.G. (1979) equation (1).

$$
\mathrm{IWUE}=\left[\mathrm{Y}_{\mathrm{gi}}-\mathrm{Y}_{\mathrm{gd}}\right] / \mathrm{IRR}_{\mathrm{i}}
$$

Where:

IWUE $=$ Irrigation water use efficiency $\left(\mathrm{kg} / \mathrm{m}^{3}\right)$.

$\mathrm{Y}_{\mathrm{gi}} \quad=$ The economic yield $(\mathrm{kg} / \mathrm{fed})$.

$\mathrm{Y}_{\mathrm{gd}} \quad=\quad$ The dry yield $(\mathrm{kg} / \mathrm{fed})$. (Actually, the crop yield without

Irrigation).

$\operatorname{IRR}_{\mathrm{i}} \quad=$ The irrigation water applied $\left(\mathrm{m}^{3} / \mathrm{fed}\right)$

* Often, in most semiarid to arid locations, $\mathrm{Y}_{\mathrm{gd}}$ may be zero.

Statistical analysis for modeling:

The data were analyzed using the two way ANOVA split plot procedure with Duncan's HSD test at $\mathrm{p}<0.05$ using the COSTAT 3.03 System software.

The simple regression models with predictor variables $X_{l} ; \ldots \ldots ; X p$ can be describe by equation (2).

$$
y=B_{0}+B_{1} X_{1}+\ldots \ldots \ldots \ldots \ldots+B_{p} X_{p}+k
$$

Where:

Variable y, called a response or dependent variable, depends on another variables $X_{(1 . . p)}$ which is called the independent or predictor variable (also called the regressor variable), $B_{0}$ is intercept, $B_{l-P}$ is the slope parameters and the variability of the error $(k)$ is constant for all values of the repressor.

\section{plant parameters.}

\section{Results and Discussion}

As shown at fig (1) the data indicated that there are not any significant effects of amounts of water on No.of leaves. However; the treatment T2 gave the highest mean value (78) for No.of Leaves compare with the other water treatments ( T1 and T3 ). On the other hand; the lowest amount of water achieved the highest mean value by $(178.16 \mathrm{~cm})$ of plant high compare with the other treatments ( T2 and T3).
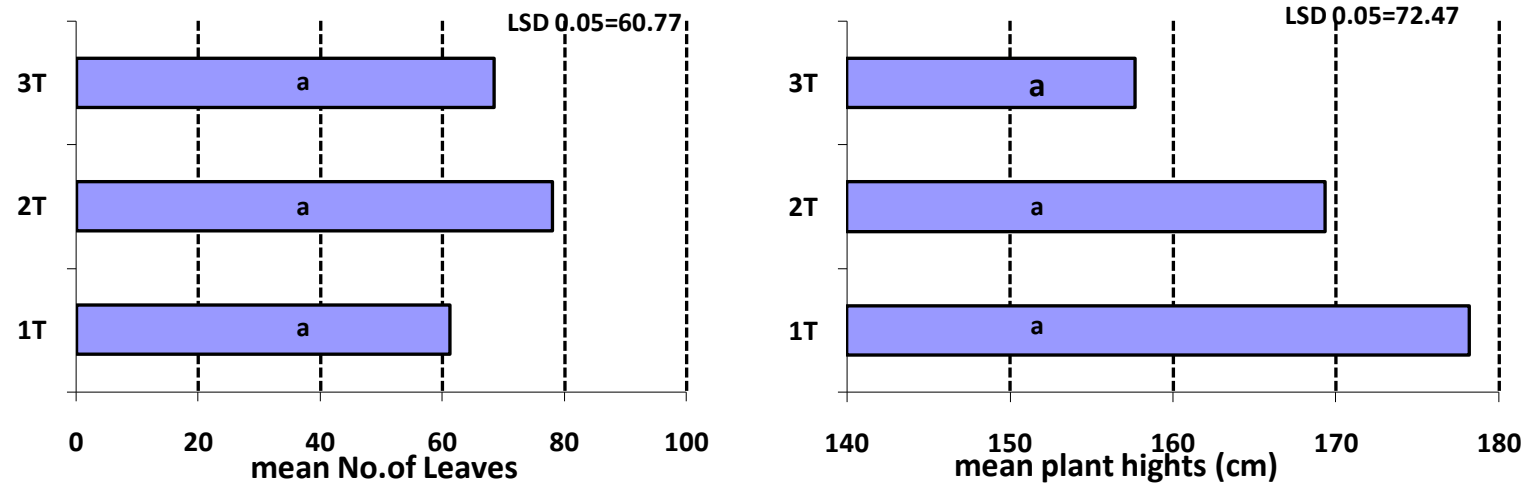

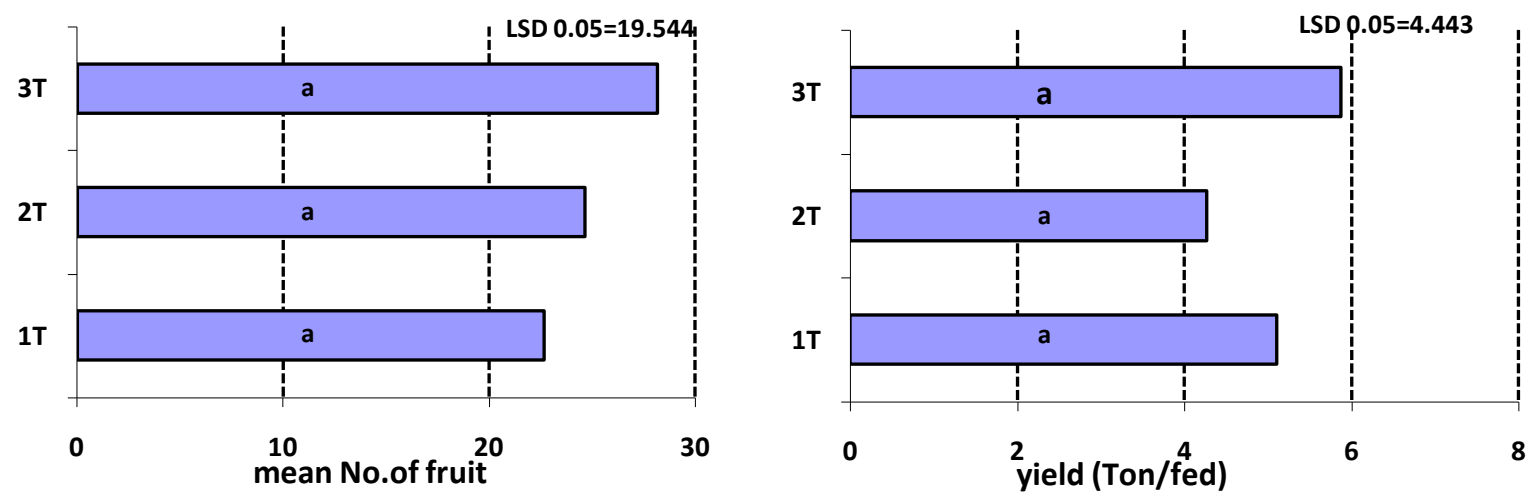

Fig(1) Effect of water quantities on some plant parameters.

Furthermore; using treatment (T3) achieved the highest mean value in both yield and No.of fruit by (5.58ton/fed) and (28.166) respectively comparing with other treatments (T1and T2).

Consequently; the data at table (5) illustrate that there are not any significant effect on plant parameters No.of leaves, fruit and plant height on the other hand; there is a significant effect on yield production for treatment $\mathrm{d} 1$ comparing with treatment $\mathrm{d} 2$ at ( LSD 0,05$)$ the $\mathrm{d} 1$ achieved (5.8 ton/fed)as a mean value. In order that; the treatment (T1) had a highest mean value in both parameters No.of fruit and plant height by 27.66 and $185.6 \mathrm{~cm}$ respectively

Table 5. Effect of plant distance on some plant parameters.

\begin{tabular}{|c|c|c|}
\hline \multirow[t]{2}{*}{ Treatments } & \multicolumn{2}{|c|}{ Plant distains ( m ) } \\
\hline & $0.50(d 1)$ & $0.75(d 2)$ \\
\hline \multirow[t]{2}{*}{ Yield ( ton/fed) } & $5.80^{b}$ & $4.17^{\mathrm{a}}$ \\
\hline & & \\
\hline \multirow[t]{2}{*}{ No. of leaves } & $59^{a}$ & $79.4^{\mathrm{a}}$ \\
\hline & & \\
\hline \multirow[t]{2}{*}{ Plant high $(\mathrm{cm})$} & $185.66^{\mathrm{a}}$ & $151.11^{\mathrm{a}}$ \\
\hline & & \\
\hline \multirow[t]{2}{*}{ No of fruit $(\mathrm{N})$} & $27.66^{\mathrm{a}}$ & $22.66^{\mathrm{a}}$ \\
\hline & & \\
\hline
\end{tabular}

\section{Irrigation water use efficiency (IWUE)}

The irrigation water use efficiency (IWUE) was evaluated using the total marketing yield divided to total water applied. Data obtained are presented in table (6). The observation of IWUE under water quantity indicated that $\mathrm{T} 1$ was highest value than $\mathrm{T} 2$ and $\mathrm{T} 3$ by $200 \%$ and $125 \%$ respectively using distance d1.Likewise, after applying distance $\mathrm{d} 2$ the IWUE for T1 is still the highest value compare with $\mathrm{T} 2$ and T3 by $92 \%$ and $800 \%$. Thus, the treatment T1 generally acquired highest value than T2 and T3 by $134 \%$ and $260 \%$ respectively. However, due to the morphology of plant that has occupied a large area of land because the leaves of this type of plant was bigger enough to make a significant Shading which effect on water evaporation and air on the pores soil. So; the performance of plant under low amount of water was perfect compare with other amounts of water.

Table 6. Irrigation water use efficiency for all treatments .

\begin{tabular}{ccccccc}
\hline & \multicolumn{7}{c}{ Water quantity $\left(\mathbf{~ m}^{3} /\right.$ fed/day) } \\
\hline & 16 & \multicolumn{7}{c}{32} & \\
\hline & 0.75 & 0.50 & 0.75 & 0.50 & 0.75 & 0.50 \\
\hline $\begin{array}{c}\text { (IWUE) } \\
\left(\mathrm{kg} / \mathrm{m}^{3} / \mathrm{fed}\right)\end{array}$ & $\mathbf{2 . 7}$ & $\mathbf{2 . 7}$ & $\mathbf{1 . 4}$ & $\mathbf{0 . 9}$ & $\mathbf{0 . 3}$ & $\mathbf{1 . 2}$ \\
\hline
\end{tabular}

Finally the regression models (using multiple regression at statistical program COStat which collect all parameters to determine the yield production under such conductions are:-

$\mathrm{Y}=\left(3.45 * 10^{(-4)} * \mathbf{Q}\right)+(5.0414 * \mathrm{D})$

$\mathrm{R}^{2}=0.73$

Where:-

$\mathrm{Y}=$ Total yield $($ Ton $/$ fed). 
$\mathrm{Q}=$ Total water applied $\left(\mathrm{m}^{3} / \mathrm{fed} / \mathrm{season}\right)$.

$\mathrm{D}=$ plant distance on plant line $(\mathrm{m})$.

\section{Conclusion}

This study leads to the following Conclusion

1- Using the low amount of water $16 \mathrm{~m} 3 / \mathrm{fed} /$ day with different distance cultivation $(0.5,0.75 \mathrm{~m})$ will increase the benefit from using unit of water and achieved the highest mean value for Irrigation water use efficiency by $(2.7$ ton/fed).

2- Cultivation in narrow distance $(0.5 \mathrm{~m})$ was the best distance for achieving the highest mean value for plant height, No.of fruits and yield production by $185.66 \mathrm{~cm}, 27$ and 5.8 ton/fed. Respectively.

3- Applying the mathematical regression can help to predicate the total yield from input factors (total water applied and plant distance)

$$
\mathrm{Y}=\left(3.45 * 10^{(-4) * \mathrm{Q})}+(5.0414 * \mathrm{D})\right.
$$

\section{References}

[1]. American Public Health Association (APHA), 1992. Standard methods for the examination of water and wastewater ( $18^{\text {th }}$ Edition ). APHA- AWWA- WPCF, Washington D.C. PP 118-130

[2]. Alghariani, S.A., 2002. Future perspectives of irrigation in southern Mediterranean region: policies and management issues. In: AlRasheed, M., Singh, V.P., Sheriff, M.M. (Eds.), Proceedings of the International Conference on Water Resources Management in Arid Regions 23-27 March, vol. 4, Kuwait, pp. 313-320.

[3]. Bos, M.G. (1979 ). Standards for irrigation efficiencies of ICID. J. Irrig. Drain. Div., ASCE, 105 (IRI), $37-43$.

[4]. Luis Santos Pereira,Theib Oweis and Abdelaziz Zairi, 2002 irrigation management under water scarcity. Agricultural water management 57 (2002) 175 - 206

[5]. Martin. R.C.(1993).Soil Sampling and Methods of analysis.( $2^{\text {nd }}$ Edition) Lewis Puplishers, Washington D.C. USA, PP 499-569

[6]. Murthy, V.R.K. 2002. Basic principles of Agricultural Meteorology. Book syndicate publishers, Koti, Hyderabad, India.

[7]. Rajurkar G, Patel N, Rajput TBS and Varghese C (2012). Soil water and nitrate dynamics under drip irrigated cabbage. Journal of Soil and Water Conservation 11(3) 196-204.

[8]. Singh J, Pandey UC, Kohli VP (1990) Response of vegetable pea to irrigation. Journal of vegetable science 17:11-15

[9]. Singh K, Vashistha RN, Pandita ML, Batra BR (1976) Effect of mulching on growth, and yield of cucurbits under rain fed condition. Journal of Haryana Horticultural Science 5:87-91.

[10]. Tan Y, Lai J, Adhikari KR, Shakya SM, Shukla AK, and Sharma KR (2009). Efficacy of mulching, irrigation and nitrogen application on bottle gourd and okra for yield improvement and crop diversification. Irrigation Drainage System 23(2) 5-41

[11]. Tindall HD (1983) Vegetables in the Tropics. Macmillan Press, London.

[12]. Zhang,H. and Oweis,T.,1999 water-yield relations and optimal irrigation scheduling of wheat in the Mediterranean region. Agric. water management .38,195-211 